\title{
Autologous Anti-CD38 A2 CAR2-expressing T-cells
}

National Cancer Institute

\section{Source}

National Cancer Institute. Autologous Anti-CD38 A2 CAR2-expressing T-cells. NCI

Thesaurus. Code C156170.

A preparation of genetically modified autologous $\mathrm{T}$-cells expressing a chimeric antigen receptor recognizing the tumor-associated antigen (TAA) cluster of differentiation 38 (CD38), with potential immunostimulating and antineoplastic activities. Upon intravenous administration, autolog ous anti-CD38 A2 CAR2-expressing T-cells are directed to and induce selective toxicity in CD38-expressing tumor cells. CD38, a type II transmembrane glycoprotein, is present on various immune cells and hematologic malignancies, and its expression has been correlated with poor prognosis. 